Joaquin Cifuentes Sepúlveda

\title{
Goce magno
}

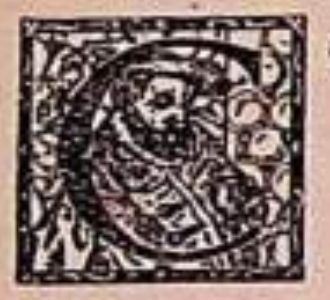

ORONA... He aqui que, al lin, la suerte me obsequia una corona viva que eres tú.

Tú, oh! esperada, margarita inocente.

Ojos de la extraña agua verde que beben los que buscan la muerte. Manos de la misma tierra entusiasta con que los hombres hacen cántaros para la leche.

Tú eres ahora mi corona.

Para mi te hicieron los que te llenaron la boca de besos y tejían rizos cuando estabas pequeña.

Para mí, que venía hacia ti desde hacía diez años con estas preguntas en la frente anhelante:

¿Conoce Ud. a la que cuando llora se hace la noche en la ciudad de los extranjeros? ¿A esa que sonríe para que los trigales maduren dos veces antes del invierno? ¿La que cuando suspira defiene el agua de los manantiales? 
¿La que canta en las sombras

para que dancen locas las perdidas estrellas?

Anda siempre leyendo debajo de los sauces...

¿No la ha visto sentada con un haz de crepúsculos

en la mano derecha? Ahl si está en todas partes.

Están ciegos Uds. -|Debe estar esperándome!

Nadie me había dicho que tú tenías la cabellera del color del otoño pasado.

Nadie me había dicho que tus manos dentro del guante

se parecian a las abejas en el estuche de los copihues.

Nadie me había dicho que, al hablar, tu boca

se llenaba de la música de los naranjos floridos.

Nadie, oh! magnílica, me había hablado

de estas cosas de tu vida.

Pero yo lo sabía todo. Oh! sí, yo lo sabia todo.

Cuando naciste, el sol entraba en Piscis

y dicen los signos del zodiaco:

mujer nacida en este tiempo

a los treinta años hallará al esposo.

Tú eres ahora mi corona.

Corona de alegría

y esperanza de arribo en el mar insondable.

De beso en las callejas en que se citan los amantes.

De recuerdo en las noches, cuando afuera,

agua $y$ nieve,

relumbra la herradura del viento.

De nostalgia en los rincones obscuros

donde los azules marineros noctámbulos abrevan una droga rubia

que le cambia el color a la vida morena. 
Tú eres ahora mi corona.

De oro como las que llevan los reyes

y eterna como las que les ponen en las batallas

a los que caen con una espada en el pecho.

Dulce corona, pura,

segura y llena de la algarabia

de los pájaros que por fin divisan el alero propicio.

Rosada y sutil como las flores que hay en las porcelanas de las lámparas.

Santa y mía como esta tristeza que es mía,

y esta esperanza que es mía

y esta mano tuya que es mía

cuando me hace señas en fus ventanas.

Corona del amor, la palpo y beso hoy que recuerdo tus palabras:

.Ese hombre nos está mirando.:

También nos miraban las estrellas.

Corona del amor en la sombra de esta tarde en que mi alma te implora:

tu boca aquí en mi boca, como la boca de ese trashumante en el borde del vaso en que beben la alegría y la aurora; fu mano aquí en mi mano, como la mano de la infanta que en un retrato juega con las palomas. 